zine sensitivity in most of the Gram-negative bacilli has reverted to its earlier levels.

\section{References}

1 Jackson, D M, Lowbury, E J L, and Topley, E, Lancet, 1951, 2, 137.

2 Cason, J S, and Lowbury, E J L, Lancet, 1960, 2, 501.

${ }^{3}$ Lowbury, E J L, et al, Lancet, 1962, 2, 958.

${ }^{4}$ Moyer, C A, et al, Archives of Surgery, Chicago, 1965, 90, 812.

${ }^{5}$ Lindberg, R B, et al, Fournal of Trauma, 1965, 5, 601.
${ }^{6}$ Fox, C L, Archives of Surgery, 1968, 96, 184.

7 Cason, J S, et al, British Medical fournal, 1966, 2, 1288.

8 Cason, J S, and Lowbury, E J L, Lancet, 1968, 1, 651.

9 Lowbury, E J L, et al, Lancet, 1971, 2, 1105.

10 Lowbury, E J L, and Jackson, D M, Lancet, 1968, 1, 654.

11 Bull, J P, Lancet, 1971, 2, 1133.

12 Lilly, H A, and Lowbury, E J L, fournal of Medical Microbiology, 1972, $5,151$.

13 Lowbury, E J L, and Jackson, D M, Injury, 1970, 1, 204.

14 Lowbury, E J L, et al, Injury, 1971, 3, 18.

15 Lowbury, E J L, et al (editors), Control of Hospital Infection: A Practical Handbook, p 191. London, Chapman and Hall, 1975.

16 Ricketts, C R, personal communication, 1975.

\title{
Epidermal architecture, growth, and metabolism in acromegaly
}

\author{
P J A HOLT, R MARKS
}

British Medical fournal, 1976, 1, 496-497

\section{Summary}

Epidermal architecture, replication, and anabolic activity were studied in six patients with acromegaly. Patients with acromegaly had significantly larger viable epidermal cells than controls. The rates of incorporation of tritiated thymidine, proline, and histidine into skin slices in vitro was also significantly increased in acromegalic patients. The mean autoradiographic labelling indices after intracutaneous injection of tritiated thymidine were $8.4 \%$ in the acromegalic patients and $5.1 \%$ in the control group. None of the changes observed could be closely correlated with levels of serum growth hormone.

\section{Introduction}

Many of the physical features of acromegaly are the result of skeletal overgrowth and generalised thickening and enlargement of soft tissue structures. The skin seems to share in this general hypertrophic process-for example, the dermis becomes thickened. ${ }^{1}$ There is also increased sebaceous gland activity. ${ }^{2}$ The aim of our study was to determine whether epidermal structure, growth, and metabolism are altered in acromegaly and to determine whether there is a correlation between any changes observed and levels of serum growth hormone.

\section{Patients and methods}

Six women aged 31-67 years (mean age 56 years) were studied and compared with a control group of 25 normal adults (17 women and 8 men aged 18-77 (mean 51 years)). Five patients were untreated, and one had undergone surgical hypophysectomy two years earlier. Acromegaly was diagnosed in each patient by clinical and radiological assessment and measurement of serum growth hormone. All the patients studied were euthyroid at the time of the study.

Department of Medicine, Welsh National School of Medicine, Heath Park, Cardiff

P J A HOLT, MB, MRCP, senior registrar in dermatology R MARKS, MB, MRCP, senior lecturer and consultant

\section{EPIDERMAL ARCHITECTURE}

Skin biopsy specimens taken from the deltoid area were fixed in $10 \%$ formalin, dehydrated, embedded in paraffin, sectioned, and stained with haematoxylin and eosin. The mean thickness of the epidermis was determined by counting the numbers of cells along an axis perpendicular to the skin surface at 30 random points and expressed as mean epidermal cell thickness (MET).

The rete pattern of the epidermis was measured by calculating the ratio of the length of the basal layer to the length of the granular cell layer (B:G ratio) using a microscope drawing tube-projection technique.

The size of epidermal cells was expressed as the mean epidermal cell diameter (MECS). This was calculated by dividing the actual thickness of the viable epidermis (in $\mu \mathrm{m}$ ) by the MET. Epidermal thickness was measured using a calibrated eye-piece graticule.

\section{EPIDERMAL GROWTH}

The replicative activity of the epidermis was studied in two ways.

In-vivo method-Biopsy specimens were taken from the deltoid area one hour after intracutaneous injection of $10 \mu \mathrm{Ci}$ of tritiated thymidine (specific activity $18 \mathrm{Ci} / \mathrm{mmol}$ ) in $0.1 \mathrm{ml}$ normal saline. Autoradiographs were prepared using a dipping method. ${ }^{3}$ The number of basal and suprabasal cells that became labelled in DNA synthesis was expressed as a percentage of the total number of basal cells (labelling index (LI)).

In-vitro method-The rate of incorporation of tritiated thymidine into skin sheets was estimated (see below). Results were expressed as corrected counts per minute $(\mathrm{cpm}) \mathrm{mm}^{2}$ tissue $^{-1}$ hour incubation ${ }^{-1}$ (thymidine units).

\section{ANABOLIC ACTIVITY}

Measurements were made of the rates of incorporation of tritiated proline (specific activity $18 \mathrm{Ci} / \mathrm{mmol}$ ) and tritiated histidine (specific activity $44 \mathrm{Ci} / \mathrm{mmol}$ ) into pieces of skin $0.4 \mathrm{~mm}$ thick and about $50 \mathrm{~mm}^{2}$ in area that had been removed from the lateral aspect of the thigh with a Castroviejo keratotome using a method simliar to that of Marks et al. ${ }^{4}$ The skin portions were incubated epidermis uppermost in Eagle's Minimal Essential Medium for four hours at $37^{\circ} \mathrm{C}$ in an atmosphere of $95 \%$ air and $5 \% \mathrm{CO}_{2}$. The radioactive precursors were added to the medium in a concentration of $1 \mathrm{mCi} / 1$ medium. Tritiated thymidine (specific activity $2 \mathrm{Ci} / \mathrm{mmol}$ ) was used to assess replicative activity. After incubation the skin was washed, homogenised, and extracted with perchloric acid. The residue was solubilised with a highly basic biological solvent (Soluene, Packard) and the contained radioactivity was measured in a scintillation counter. The results were expressed as corrected $\mathrm{cpm} \mathrm{mm}^{2}$ tissue ${ }^{-1}$ hour incubation $^{-1}$ (proline or histidine units). 


\section{Results}

The results are shown in the table. The cells were about $40 \%$ larger in patients with acromegaly than in controls. Although the labelling index (see figure) and proline, histidine, and thymidine incorporation were significantly higher in the acromegalic group, there was no significant correlation between these measurements and serum growth hormone expressed as either fasting growth hormone level or the minimum concentration of growth hormone achieved (expressed as percentage change) during a glucose tolerance test.

Mean ( $\pm S E$ of mean) results of investigation into epidermal architecture, growth, and metabolism

\begin{tabular}{|c|c|c|c|}
\hline & $\begin{array}{l}\text { Patients with } \\
\text { acromegaly }\end{array}$ & Controls & Significance \\
\hline $\begin{array}{l}\text { B:G ratio } \\
\text { MET } \\
\text { MECS ( } \mu \mathrm{m}) \\
\text { LI (\%) } \\
\text { Proline incorporation } \\
\text { (proline units) } \\
\text { Histidine incorporation } \\
\text { (histidine units) } \\
\text { Thymidine incorporation } \\
\text { (thymidine units) }\end{array}$ & $\begin{array}{c}1 \cdot 11 \pm 0 \cdot 04 \\
3 \cdot 4 \pm 0 \cdot 1 \\
15 \cdot 6 \pm 0 \cdot 3 \\
8 \cdot 4 \pm 0 \cdot 3 \\
110 \pm 15 \cdot 1 \\
42 \cdot 0 \pm 9 \cdot 3 \\
49 \cdot 0 \pm 2 \cdot 8\end{array}$ & $\begin{aligned} 1 \cdot 12 & \pm 0 \cdot 02 \\
4 \cdot 5^{2} & \pm 0 \cdot 2 \\
11 \cdot 4 & \pm 0 \cdot 4 \\
5 \cdot 1 & \pm 0 \cdot 4 \\
59 \cdot 7 & \pm 7 \cdot 4 \\
22 \cdot 1 & \pm 2 \cdot 5 \\
15 \cdot 1 & \pm 2 \cdot 3\end{aligned}$ & $\begin{array}{l}\quad \text { NS } \\
P<0.001 \\
P<0.001 \\
P<0.001 \\
P<0.001 \\
P<0.05 \\
P<0.001\end{array}$ \\
\hline
\end{tabular}

NS $=$ Not significant

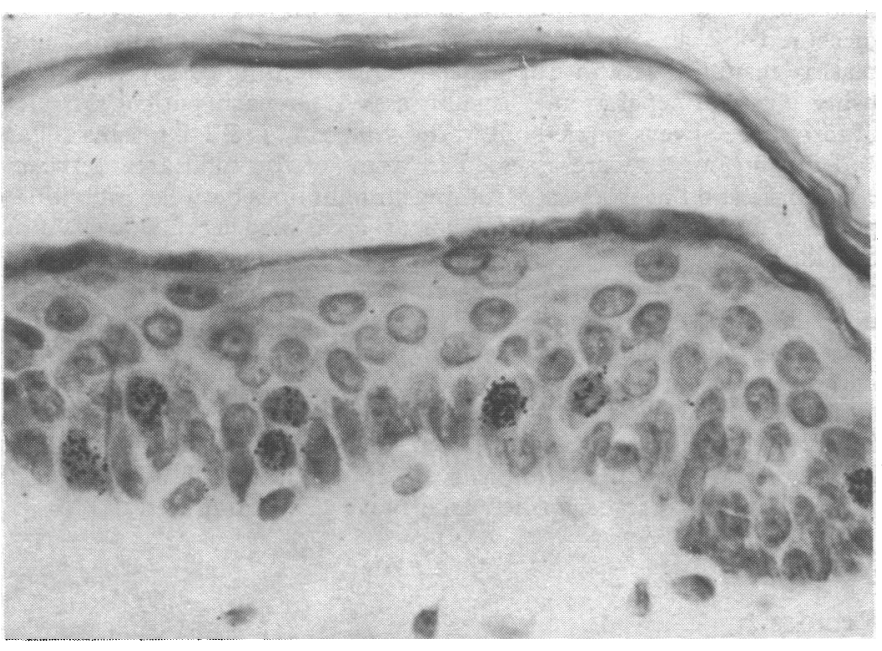

FIG 1-Autoradiograph of skin taken from patient with acromegaly. (H and $\mathbf{E}$ $\times 87$.)

\section{Discussion}

The increased epidermal labelling index together with the significantly increased size of the viable epidermal cells strongly suggest that in acromegaly there is both hyperplasia and hypertrophy of the epidermis. Growth hormone may be responsible for this. Moon et $a l^{5}$ showed that adding human growth hormone to human liver cells in culture produced increased cell replica- tion, which was abolished by antibody to human growth hormone, which suggested that human growth hormone may have a direct effect at the tissue level.

Proline and histidine are incorporated into proteins that are continuously formed in maturing epidermis and, as such, their rates of incorporation are a measure of the metabolic activity of the epidermis. The significantly increased incorporation of these amino-acids in acromegaly suggests that epidermal cell metabolism is enhanced in this disorder. Growth hormone may be partly responsible for this. Jefferson and Korner $^{6}$ have shown that amino-acid incorporation by perfused rat liver can be stimulated directly by growth hormone.

The incorporation of precursors in our specimens was mostly epidermal and not dermal. The dermal component of a keratotome specimen occupies less than $15 \%$ of the total thickness of the specimen and is made up of comparatively hypocellular material. Autoradiographs of skin incubated in the presence of tritiated proline show that the bulk of the incorporation is in fact epidermal. ${ }^{7}$ If the incorporations of proline and histidine are corrected for the slightly changed epidermal thickness the results show the same trend, incorporation in acromegaly remaining significantly raised.

Lack of precise information on precursor pool size and the possible alteration of this value in acromegaly prohibit us from deducing from the altered rates of incorporation that there are altered rates of synthesis of macromolecules. Because the amount of precorsor added is comparatively large ${ }^{8}$ however, it seems probable that in epidermis that is not grossly altered by disease protein synthesis parallels amino-acid incorporation. The changes in epidermal cell size, replication, and metabolism correlate poorly with growth hormone levels, possibly because growth hormone is only one of several factors affecting epidermopoiesis in acromegaly. Epidermopoeisis is increased in thyrotoxicosis ${ }^{9}$ and thyroid hormone may be partly responsible for this. It should be noted, however, that levels of serum growth hormone concentrations seem to correlate poorly with other indicer of the effects of excessive growth hormone secretion. ${ }^{10}$

We thank Dr Picton Thomas for allowing us to study patients under his care. $R M$ is in receipt of a grant from the Wellcome Trust.

\section{References}

1 Black, M M, Shuster, S, and Bottoms, E, Clinical Endocrinology, 1972, 1, 259.

2 Burton, J L, et al, British Medical fournal, 1972, 1, 406.

Marks, R, and Wells, G C, British fournal of Dermatology, 1973, 88, 249.

4 Marks, R, Fukui, K, and Halprin, K, British fournal of Dermatology, $1971,84,453$.

5 Moon, H D, Gentoft, V L, and Li, C H, Endocrinology, 1962, 70, 31.

- Jefferson, L S, and Korner, A, Biochemical fournal, 1967, 104, 826.

7 Marks, R, British Fournal of Dermatology, 1975, suppl 11, p 28.

8 Smets, L A, Fournal of Cell Physiology, 1969, 74, 63.

- Holt, P J A, Lazarus, J, and Marks, R, in press.

10 Aloia, J F, Field, R A, and Kramer, S, Archives of Internal Medicine, 1973, $131,509$. 